\title{
Macrophage Inflammatory Protein 1
}

Gamma Measurement

National Cancer Institute

\section{Source}

National Cancer Institute. Macrophage Inflammatory Protein 1 Gamma Measurement.

NCI Thesaurus. Code C130164.

The determination of the amount of macrophage inflammatory protein $1 \mathrm{gamma}$ present in a sample. 